\title{
Econometric Analysis of Export Led Growth in the Nigerian Economy
}

\author{
Adelakun Ojo Johnson ${ }^{1} \&$ Olatunde Kazeem Olayiwola ${ }^{2}$ \\ ${ }^{1}$ Department of Economics, School of Accounting, Economics \& Finance, College of Law \& Management Studies, \\ University of KwaZulu-Natal, Durban, South Africa \\ ${ }^{2}$ The Department of Economics, Faculty of Arts and Social Sciences, Kingston University, London, United \\ Kingdom \\ Correspondence: Adelakun Ojo Johnson, Department of Economics, School of Accounting, Economics \& Finance, \\ College of Law \& Management Studies, University of KwaZulu-Natal, Durban, South Africa.
}

Received: February 27, 2020; Accepted: May 29, 2020; Published: June 5, 2020

\begin{abstract}
This study investigates the role of export in the economic growth process of Nigeria with using the three sample periods of annual time series data, which are 1961 to 2013, 1970 to 2013 and 1981 to 2013 respectively. The variables for this period of 1961 to 2013 are GDP growth and exports/GDP ratio, the variables for this period of 1970 to 2013 are GDP growth, exports/GDP ratio, Imports/GDP ratio and the real interest rate and the variables for the last period of data are total exports, manufacturing GDP, agricultural GDP, manufacturing exports and agricultural exports respectively. The VAR Granger causality results for the first sample period show no causal relationship between exports and the GDP growth which illustrates that the two variables are independent of each other. The VAR results for the period of 1970 to 2013 show no causality between the variables under consideration. Following the results of the Granger causality test for this last period of 1981 to 2013, the results show no evidence of causality existing among the variables, which do not show evidence for the support for the export-led growth in the Nigerian economy. This study concluded that exports do not influence and cannot sustain economic growth in the Nigerian economy. The study recommended that an attempt should be made towards executing an economic policy that will strengthen the economic growth of Nigeria.
\end{abstract}

Keywords: growth, Export, VAR, Granger Causality, Nigeria

JEL Code: E2, E3, E6, F3, F4.

\section{Introduction}

Import substitution and export promotion are two contrasting strategies for industrial development that have been adopted by different countries or even the same country at different times. Discussion of the relative advantages of these two strategies has provided a focus for debate between "trade pessimists" - who favour restrictions on imports, and "trade optimists" - who support free trade in goods and services (UK Essays, November 2013). Between the 1950s and the 1960s, the trade pessimists who favour restrictions on imports prevailed in this debate, so discouraging importation of goods and services in the developing countries. After the 1970s, the trade optimists who support free trade in goods and services overcame the trade pessimists thereby encouraging countries to sell goods to other countries (UK Essays. November 2013).

The policy stance associated with trade pessimists is known as 'Import Substitution' which can be defined as an economic policy directed at imposing restrictions or barriers to the importation of foreign goods by replacing them with locally made goods to reduce dependency on imported goods and make the economy self-sufficient to avoid dumping. (UK Essays. November 2013). Dumping is a process of selling a product in a foreign country for less than the price in a domestic country. Dumping can be prevented by subsidizing exports (Business Dictionary.com).

In contrast, 'Export promotion,' a policy stance associated with trade optimists, can be defined as an economic policy directed at speeding up the industrialization process of a country by exporting goods and services for which the nation has a comparative cost advantage (UK Essays. November 2013). The comparative cost advantage is an economic argument, which annotates that a country should specialize in producing and exporting only those goods, and services, which it can produce more efficiently at minimum cost than other goods and services, which it should import. It occurs from different endowments of factors of production. By comparative cost advantage, countries can acquire more foreign exchange, which will raise the standard of living of the countries involved and increases the gross domestic products (GDP) of the country (Business Dictionary.com). 
The major purpose of this study is to test the validity of the export-led growth hypothesis in the Nigerian economy, to ascertain if the economy is driven by export performance, which in turn leads to economic growth, and propound some recommendations for improvement based on the findings of the study.

The Nigerian economy has engaged in various strategies such as the import substitution strategy measures, which are aimed at replacing foreign goods with locally, made ones. The adoption of this strategy was targeted at reducing importation and reduction of foreign exchange reserves in the early 1980s. Because of the inefficiency of the import substitution strategy, a structural adjustment programme (SAP) came into existence in 1986 of which export promotion becomes the key component to enhance economic growth of the country by encouraging domestic production for exports in other sectors of the economy aside from the crude oil sector (Santos and Bernard, 2012).

Due to the adoption of this strategy (SAP), Nigeria has emerged as Africa's largest economy, with a GDP estimated at US\$ 479 billion as at 2014 while crude oil has been the main source of government revenue since the 1970s. Investment in crude oil and natural gas was subject to regulatory constraints and encountered security risks, which led to a contraction of Nigeria's crude oil sector in the year 2012-2013. The Nigerian economy still grows rapidly at $6 \%-8 \%$ per annum because of growth in agriculture, telecommunications, and services and the medium-term outlook for Nigeria should show improvement if oil output and prices remain stable. Fiscal authorities pursued countercyclical policies, i.e. policies aimed at encouraging spending during the depression and tighten up credit during inflationary periods. This countercyclical policy reduces budget deficits significantly. The monetary policy has also contracted due to the countercyclical policies of the fiscal authorities. During the period of the global financial crises in 2008-2009, the banking sector was effectively recapitalized and subject to enhanced regulation.

Despite the strength of Nigeria's economy, there have been problems such as inadequate power supply, lack of infrastructural facilities, slow rate of legislative reforms, restrictive trade policies, insecurity, high rate of corruption, delays in legislative reforms and inconsistency towards environmental issues. Economic diversification and optimum growth have not been achieved, as there is a high level of poverty, which is caused by an increase in unemployment. More than $62 \%$ of the Nigerian population live in extreme poverty. Due to these economic problems faced by the country, President Jonathan has entrenched economic teams with high reputable members to reduce poverty level by diversifying production and improving efficiency by developing public-private partnerships for roads, agriculture and power (Central Intelligence Agency, 2014).

The rest of this paper is structured as follows; section two presents the related literature concerning exports and economic growth and the Empirical literature. The methodology, which comprises of the data sources and description, Estimation techniques and model formulation, is described in section three while data analysis and discussion will be made in section four, concluding comments in section five will reflect the conclusions and recommendation based on the findings of the study.

\section{Empirical Literature}

Many studies have found pragmatic support for the export-led growth hypothesis for a majority of economies. For instance, Bahmani and Alse (1993) cited in Musleh (2004) investigated the relationship for nine developing countries within the framework of an Error Correction Model, and they found substantial support for the exportled growth hypothesis for all the countries enclosed in the sample. In the additional study along the same lines, Xu (1996), cited in Musleh (2004) found evidence of the export-led growth in 17 out of 32 developing countries included in the analysis.

Recent studies also provided evidence on Asian countries on the relationship between exports and economic growth. For instance, Taghavi, et al. (2012), cited in Achchuthan (2013) investigated the import, export and economic growth in Iran throughout 1962-2011. The results demonstrated a long-run relationship between import, export and economic growth. Based on the results, export had both a direct and positive relationship with economic growth in the long-run. Besides, import had a significant and negative relationship with economic growth and had a negative effect on economic growth in the long-run. It was concluded that export had a positive effect on economic growth than import.

Several studies also provided evidence that export-led growth does not occur in southern Asian countries like Cambodia. For instance, Tang and Wong (2011), cited in Tang and Chea (2013) found a causal relationship between foreign direct investment (FDI), exports and imports of merchandise and services for the case of Cambodia. Their results demonstrated that foreign direct investment (FDI) not only can boost merchandise and services exports but also indicated the presence of forwarding and backward linkages, which could result in positive externalities, which does not give conclusive support to the export-led growth hypothesis. Several studies also provided evidence for the support for the export-led growth in developed countries, particularly in China. For instance, Bond et al (2004), cited in Herrerias and Orts (2010) found evidence of an increase in investment as a 
share of GDP, which resulted in a greater rate of growth in output per worker for china economy. Jones (1995), cited in Herrerias and Orts (2010) concluded that AK growth models do not give a good description of growth in 15 selected OECD countries. While Blamestormet al (1996), cited in Herrerias and Orts (2010) found a causality between investment and economic growth in the China economy. Nevertheless, the contrapositive view can also be found in the empirical literature. For example, Bond et al. (2004), cited in Herrerias and Orts (2010) found evidence that an increase in investment as a share of GDP results in a greater rate of growth in output per worker in the China economy.

Also, Chow (1993), cited in Herrerias and Orts (2010) showed evidence of the export-led growth hypothesis on the Chinese economy. Chow emphasises the role of capital accumulation as the main source of economic growth for china from the 1950s until the end of the 1980s but there was no evidence of any technological progress during this period. Yusuf (1994), cited in Herrerias and Orts (2010) argued that capital accumulation is not the only element of economic growth but also technological progress played an important role from 1978 until 1993. Hu and khan (1996) and Caruso (2002), cited in Herrerias and Orts (2010) argued in contrast to Chow's view that growth in productivity rose sharply in during the early years of reform and positive during the preform period. Finally, Qin et al. (2005), cited in Herrerias and Orts (2010) found some evidence that output drives investment in the Chinese economy.

Several studies also provided evidence that does not support the export-led growth of the Malaysian economy. For instance, Lee and Pan (2000) cited in Mahadevan (2007) used non-linear causality tests to show that there was no causal relationship between exports or trade and GDP for Malaysia. Diks and Panchenko (2005), cited in Mahadevan (2007) showed that these non-linear tests have a consistency problem and the rejection rate of noncausality is high as the sample size increases. According to the World Bank (2009), cited in Dreger and Herzer (2011), many developing countries Such as Africa are subject to redundant business and labour regulations that limit both the mobility of factors of production and factor prices. In such a situation of severe factor-market imperfections, an increase in exports may be affiliated with an under-employment, which may, in turn, leads to loss of production activities or productivity losses.

Some authors were able to show supports for the export-led growth particularly in the Nigerian Economy according to Ekpo and Egwaikhide (1994), Fajana (1979) and Langley (1968) cited in Ojide and Ogbodo (2014). It can be concluded from the empirical studies that there arises to be a causal relationship between exports and economic growth.

\section{Model}

\subsection{The Vector Autoregressive Model (VAR)}

The Vector Autoregressive Model is used to capture the linear interdependencies among multiple time series. A VAR model extends the univariate autoregression (AR) to a list, or "vector", of time series variables. An $n^{\text {th }}$ order VAR is also called a VAR with $n$ lags. The lag lengths in a VAR can be decided using either F-tests or information criteria (Stock \& Watson, 2012). This study will apply a VAR model to investigate the causal relationship between the GDP and other variables. It is relevant to transpose the GDP by computing its first difference, $\Delta$ GDP. The VAR equation form for $\Delta$ GDP for the period of 1970 to 2013 is as follows:

$$
\Delta G D P_{t}=\alpha_{1}+\sum_{i=0}^{n} \beta_{1} \Delta G D P_{t-i}+\sum_{i=0}^{n} \gamma_{1} \Delta E X P_{t-i}+\sum_{i=0}^{n} \delta_{1} \Delta I M P_{t-i}+\sum_{i=0}^{n} \partial_{i} \Delta R I R_{t-i}+\varepsilon_{t}
$$

Where: $\Delta \mathrm{GDP}=$ Change in Real Gross Domestic Products (proxy for economic growth); $\Delta \mathrm{EXP}=$ Change in Real Exports; $\Delta$ IMP $=$ Change in Real Imports; $\Delta$ RIR $=$ Change in Real Interest Rate; $\varepsilon=$ White-Noise i.e. $\varepsilon_{t} \sim$ i. i. $d\left(0, \sigma^{2}\right)$ and $\operatorname{cov}\left(\varepsilon_{y}, \varepsilon_{t}\right)=0$

\subsection{Further Examination of the Export-Led Growth Hypothesis}

The Granger causality test will also be used for other examination of the validity of the export-led growth hypothesis by considering the following equations in manufacturing and agricultural sector of the Nigerian economy from 1981 to 2013 to ascertain if there is any causal relationship between exports and growth and which are as follows:

- An equation system for the Manufacturing GDP and Total exports is written as:

$$
\begin{aligned}
M G D P_{t} & =\sum_{j=1}^{p} \alpha_{j} M G D P_{t-j}+\sum_{j=1}^{p} \beta_{j} T E_{t-j}+\mu_{1 t} \\
T E_{t} & =\sum_{j=1}^{p} \alpha_{j} T E_{t-j}+\sum_{j=1}^{p} \beta_{j} M G D P_{t-j}+\mu_{2 t}
\end{aligned}
$$

- An equation system for the Agricultural GDP and Total Exports is written as: 


$$
\begin{gathered}
A G D P_{t}=\sum_{j=1}^{p} \alpha_{j} A G D P_{t-j}+\sum_{j=1}^{p} \beta_{j} T E_{t-j}+\mu_{1 t} \\
T E_{t}=\sum_{j=1}^{p} \alpha_{j} T E_{t-j}+\sum_{j=1}^{p} \beta_{j} A G D P_{t-j}+\mu_{2 t}
\end{gathered}
$$

- An equation system for Manufacturing exports and the Manufacturing GDP is written as:

$$
\begin{aligned}
M E_{t} & =\sum_{j=1}^{p} \alpha_{j} M E_{t-j}+\sum_{j=1}^{p} \beta_{j} M G D P_{t-j}+\mu_{1 t} \\
M G D P_{t} & =\sum_{j=1}^{p} \alpha_{j} M G D P_{t-j}+\sum_{j=1}^{p} \beta_{j} M E_{t-j}+\mu_{2 t}
\end{aligned}
$$

- An equation system for Manufacturing exports and the Agricultural GDP is written as:

$$
\begin{gathered}
M E_{t}=\sum_{j=1}^{p} \alpha_{j} M E_{t-j}+\sum_{j=1}^{p} \beta_{j} A G D P_{t-j}+\mu_{1 t} \\
A G D P_{t}=\sum_{j=1}^{p} \alpha_{j} A G D P_{t-j}+\sum_{j=1}^{p} \beta_{j} M E_{t-j}+\mu_{2 t}
\end{gathered}
$$

- An equation system for Agricultural exports and the Manufacturing GDP is written as:

$$
\begin{aligned}
A E_{t} & =\sum_{j=1}^{p} \alpha_{j} A E_{t-j}+\sum_{j=1}^{p} \beta_{j} M G D P_{t-j}+\mu_{1 t} \\
M G D P_{t} & =\sum_{j=1}^{p} \alpha_{j} M G D P_{t-j}+\sum_{j=1}^{p} \beta_{j} A E_{t-j}+\mu_{2 t}
\end{aligned}
$$

- An equation system for the Agricultural GDP and Agricultural exports is written as:

\section{Data Analysis and Discussion}

$$
\begin{aligned}
A E_{t} & =\sum_{j=1}^{p} \alpha_{j} A E_{t-j}+\sum_{j=1}^{p} \beta_{j} A G D P_{t-j}+\mu_{1 t} \\
A G D P_{t} & =\sum_{j=1}^{p} \alpha_{j} A G D P_{t-j}+\sum_{j=1}^{p} \beta_{j} A E_{t-j}+\mu_{2 t}
\end{aligned}
$$

\subsection{Vector Autoregressive Model}

The study proceeds to develop the VAR model of the GDP growth, imports/GDP ratio, real interest rate and the exports/GDP ratio. Using the optimal lag of one (1) selected by four different criteria: Sequential Modified LR Test Statistic (LR), Final Prediction Error (FPE), Schwarz Information Criteria (SC) and Hannan-Quinn Information Criterion (HQ). The study put into consideration the serial correlation of the VAR residuals of the variables and the serial correlation test results can be presented in the table below:

Table 4.3.2.1 The Var Residual Correlation LM Test

\begin{tabular}{lll}
\hline Lag & LM-Stat & Prob.values \\
\hline 1 & 16.418 & 0.424 \\
\hline
\end{tabular}

Hypothesis:

$\boldsymbol{H}_{\boldsymbol{O}}$ : There is no Autocorrelation

$\boldsymbol{H}_{1}$ : There is Autocorrelation

Table 4.3.2.1 above reports the VAR residual correlation LM tests with a lag of one and LM-Stat calculated as 16.418 with its probability values of $42.4 \%$, which is greater than the $5 \%$ level of significance. The null hypothesis $\left(H_{0}\right)$ of no autocorrelation is accepted and this result explains that the VAR residuals are not serially correlated only at the lag of one. The stability condition check can be presented in the table below:

Table 4.3.2.2 The Var Stability Condition

\begin{tabular}{lc}
\hline Root & Modulus \\
\hline 0.638 & 0.638 \\
0.472 & 0.472 \\
0.196 & 0.196 \\
-0.080 & 0.080 \\
No root lies outside the unit circle. & \\
VAR satisfies the stability condition. & \\
\hline
\end{tabular}

Table 4.3.2.2 displays the VAR stability condition of the GDP growth, imports/GDP ratio, real interest rate and exports/GDP ratio with their roots and modulus values respectively. The modulus values of $0.638,0.472,0.196$ and 0.080 respectively are less than 1.00 in absolute values, which means that the VAR satisfies the stability 
condition of stationarity. The VAR result showing the GDP growth, imports GDP ratio, real interest rate and exports/GDP ratio can be presented in the table below:

Table 4.3.2.3 The Vector Autoregressive Model for the Period of 1970 - 2013

\begin{tabular}{lllll}
\hline & GDP GROWTH & IMPORTS & REAL INTEREST RATE & EXPORTS \\
\hline GDP GROWTH (-1) & 0.255 & 0.093 & 0.343 & 0.003 \\
& $(0.142)$ & $(0.010)$ & $(0.295)$ & $(0.152)$ \\
& {$[1.799]$} & {$[0.937]$} & {$[1.165]$} & {$[0.018]$} \\
\hline IMPORTS (-1) & 0.361 & 0.423 & 0.098 & -0.040 \\
& $(0.202)$ & $(0.141)$ & $(0.412)$ & $(0.217)$ \\
& {$[1.794]$} & {$[2.980]$} & {$[0.234]$} & {$[-0.186]$} \\
\hline REAL INTEREST RATE (-1) & -0.108 & -0.123 & -0.137 & -0.001 \\
& $(0.078)$ & $(0.055)$ & $(0.162)$ & $(0.084)$ \\
& {$[-1.398]$} & {$[-2.244]$} & {$[-0.848]$} & {$[-0.012]$} \\
\hline EXPORTS (-1) & 0.010 & 0.318 & 0.469 & 0.686 \\
& $(0.131)$ & $(0.093)$ & $(0.273)$ & $(0.141)$ \\
& {$[0.078]$} & {$[3.442]$} & {$[1.716]$} & {$[4.852]$} \\
\hline C & -5.306 & 2.239 & -19.281 & 9.941 \\
& $(3.975)$ & $(2.799)$ & $(8.276)$ & $(4.279)$ \\
& {$[-1.335]$} & {$[0.798]$} & {$[-2.330]$} & {$[2.323]$} \\
\hline
\end{tabular}

$\mathrm{R}^{2}=0.17$

Note: The table reports the VAR standard error in brackets and in parentheses, the absolute t-ratios; exports equals' exports/GDP ratio and imports equals imports/GDP ratio.

From the VAR results, the R-squared value of $17 \%$ explains the proportion of variation in the endogenous variables explained jointly by the exogenous variables in the model is $17 \%$ leaving a whooping of $83 \%$ to an unexplained variation. By implication, the explanatory power of the model is very low in the sense that the R-squared value of $17 \%$ which is less than $60 \%$ in absolute values. The model possibly omits some important variables. Although a low R-squared value does not necessarily mean that, there is an omitted variable bias in the regression model (Stock and Watson, 2012).

Also from the table, it can be observed that the estimated impact of GDP growth at one lag period on the current GDP growth, imports, real interest rate and exports ratio respectively is not statistically significant with absolute t-ratios $(1.799,0.937,1.165$ and 0.018$)$ which are less than the $5 \%$ two-tailed critical value of 2.000 . There is no $95 \%$ confidence that the values of GDP growth at one period lag falls in the confidence interval. By implication, GDP growth at one lag period does not have any importance on the endogenous variables. Also, the estimated impact of Imports at one lag period on the current GDP growth, real interest rate and exports are not statistically significant with absolute t-ratios $(1.794,0.234$ and -0.186$)$ respectively which are less than the $5 \%$ two-tailed critical value of 2.000 . While the estimated impact of imports at one lag period on the current imports is statistically significant with absolute t-ratios of 2.980 greater than the $5 \%$ two-tailed critical value of 2.000 . By indication, imports at one lag period only have control of the current imports.

Moreover, the estimated impact of the real interest rate at one lag period on the current GDP growth, real interest rate and exports are not statistically significant with absolute t-ratios $(-1.398,-0.848$ and -0.012$)$ respectively which are less than the $5 \%$ two-tailed critical value of 2.000 . While the estimated impact of the real interest rate at one period ago on imports is statistically significant with absolute t-ratios ( -2.244$)$ greater than the $5 \%$ two-tailed critical value of 2.000. By indication, the real interest rate at one lag period only has control over the current imports. The estimated impact of exports at one lag period on both the current GDP growth and real interest rate respectively is not statistically significant with absolute t-ratios $(0.078,1.716)$ which are less than the $5 \%$ twotailed critical value of 2.000. While the estimated impact of exports at one lag period on both the current imports and exports is statistically significant with absolute t-ratios $(3.442,4.852)$ greater than the $5 \%$ two-tailed critical value of 2.000. By implication, exports at one lag period only have an impact on both the current exports and imports.

Finally, the intercept of the model is not statistically significant on both the current GDP growth and imports with absolute t-ratios $(-1.335,0.798)$ which are less than the critical value of 2.000 . While the intercept is statistically 
significant on both the current real interest rate and exports respectively with t-ratios $(-2.330,2.323)$ greater than the $5 \%$ two-tailed critical value of 2.000. The outcome of the VAR model illustrated in table 4.3.2.3 above does not show any causal relationship between the GDP growth and other variables for the period of 1970 to 2013.

Table 4.3.3.4 The Var Granger Causality/ Exogeneity Wald Tests of Gdp Growth and Exports for the Period of 1961 to 2013

\begin{tabular}{|c|c|c|c|}
\hline Null Hypothesis: & Chi-Square & Prob.values & Outcome \\
\hline $\begin{array}{l}\text { GDP growth does not Granger } \\
\text { Cause exports }\end{array}$ & 0.209 & 0.993 & No Causality \\
\hline $\begin{array}{l}\text { Exports do not Granger Cause GDP } \\
\text { Growth }\end{array}$ & 0.000 & 0.643 & No Causality \\
\hline
\end{tabular}

Note: Exports $=$ Exports/GDP ratio

\section{Hypothesis:}

$\boldsymbol{H}_{\mathbf{0}}$ : There is no Uni-directional or Bi-directional causality between GDP growth and Exports.

$\boldsymbol{H}_{\mathbf{1}}$ : There is Uni-directional or Bi-directional causality between GDP growth and Exports.

Table 4.3.3.4 above summarises the Granger Causality test results of the GDP growth and exports with their calculated Chi-square and probability values respectively.

From the table, GDP growth does not granger cause exports according to its probability value of $99.3 \%$ which is greater than the $5 \%$ level of significance, and exports do not Granger cause GDP growth according to its probability values of $64.3 \%$ which is greater than $5 \%$ level of significance. On the basis of these results, the null hypothesis $\left(H_{0}\right)$ is accepted.

Table 4.3.3.4 concluded that causality does not exist between GDP growth and exports for the period of 1961 to 2013 which demonstrated that the two variables are independent of each other.

Table 4.4.1 The Augmented Dickey-Fuller Unit Root Test for the Period of 1981 - 2013

\begin{tabular}{|c|c|c|c|}
\hline \multirow[b]{2}{*}{ Variable } & \multicolumn{3}{|c|}{ ADF Test Statistics } \\
\hline & $\begin{array}{l}\text { Level Constant without } \\
\text { trend }\end{array}$ & Order of Integration & $\underline{\text { Remarks }}$ \\
\hline TOTAL EXPORTS & $\begin{array}{l}-3.492 \\
(0.015)\end{array}$ & $\mathrm{I}(0)$ & Stationary \\
\hline MANUFACTURING GDP & $\begin{array}{l}6.031 \\
(0.000)\end{array}$ & $\mathrm{I}(0)$ & Stationary \\
\hline AGRICULTURAL & -4.287 & & \\
\hline EXPORTS & $(0.002)$ & $\mathrm{I}(0)$ & Stationary \\
\hline AGRICULTURAL & -5.249 & & \\
\hline GDP & $(0.000)$ & $\mathrm{I}(0)$ & Stationary \\
\hline MANUFACTURING & -6.857 & & \\
\hline EXPORTS & $(0.000)$ & $\mathrm{I}(0)$ & Stationary \\
\hline
\end{tabular}

Note: The table reports the ADF t-statistics and, in parentheses, the probability values.

\section{Hypothesis:}

$\boldsymbol{H}_{\mathbf{0}}$ : There is a unit root (Non-Stationary)

$\boldsymbol{H}_{\mathbf{1}}$ : There is no unit root (Stationary).

From table 4.4.1 above, the test result of the ADF statistics shows that all the variables are all stationary at a level without trend with their respective probability values, which are less than the $5 \%$ level of significance. The null hypothesis $\left(H_{0}\right)$ of no stationarity is accepted and these results concluded that the variables are stationary. The results in table 4.4.1 above do not also support the use of the Engle-Granger method of cointegration since they are not I (1) variables. 
Table 4.4.2 The Var Residual Correlation LM Test

\begin{tabular}{lll}
\hline Lag & LM-Stat & Prob.values \\
\hline 1 & 18.651 & 0.814 \\
\hline
\end{tabular}

Hypothesis:

$\boldsymbol{H}_{\boldsymbol{O}}$ : There is no Autocorrelation

$H_{1}$ : There is Autocorrelation

Table 4.4.2 above presents the VAR residual correlation of total exports, manufacturing GDP, agricultural exports, agricultural GDP and manufacturing exports LM tests at one lag with LM-Stat calculated as 18.651 and probability values of $81.4 \%$, which is greater than the $5 \%$ level of significance. The null hypothesis $\left(H_{0}\right)$ is accepted and this result means that the VAR residual is not serially correlated only at the specified lag of one.

Table 4.4.3 The Var Stability Condition

\begin{tabular}{ll}
\hline$\underline{\text { Root }}$ & $\underline{\text { Modulus }}$ \\
\hline $0.610-0.104 \mathrm{i}$ & 0.619 \\
$0.610+0.104 \mathrm{i}$ & 0.619 \\
-0.170 & 0.170 \\
0.059 & 0.059 \\
-0.040 & 0.040 \\
No root lies outside the unit circle. & \\
VAR satisfies the stability condition. & \\
\hline
\end{tabular}

The modulus values of $0.619,0.170,0.059$ and 0.040 respectively are less than 1.00 in absolute values, which demonstrates that the VAR satisfies the stability condition of stationarity since no root lies outside the unit circle. The condition of no serial correlation in the VAR, residual is satisfied and consistent with stationarity, which can be seen in tables 4.4.2 and 4.4.3 respectively.

Table 4.5 The Pairwise Granger Causality Test for the Period of 1981 to 2013

\begin{tabular}{|c|c|c|c|}
\hline Null Hypothesis: & $\underline{\text { F-Stat }}$ & Prob.values & Outcome \\
\hline$\overline{\text { Manufacturing GDP does not granger cause Total exports }}$ & $\overline{1.849}$ & 0.184 & $\overline{\text { No causality }}$ \\
\hline Total exports do not granger cause Manufacturing GDP & 1.002 & 0.325 & \\
\hline Agricultural GDP does not granger cause Total exports & 0.732 & 0.399 & No causality \\
\hline Total exports do not granger cause agricultural GDP & 0.589 & 0.449 & \\
\hline Manufacturing exports does not granger cause manufacturing GDP & 0.188 & 0.668 & No causality \\
\hline Manufacturing GDP does not granger cause manufacturing exports & 1.782 & 0.192 & \\
\hline Manufacturing exports does not granger cause agricultural GDP & 0.187 & 0.892 & No causality \\
\hline Agricultural GDP does not granger cause manufacturing exports & 0.562 & 0.460 & \\
\hline Agricultural exports do not granger cause manufacturing GDP & 0.034 & 0.855 & No causality \\
\hline Manufacturing GDP does not granger cause agricultural exports & 1.439 & 0.240 & \\
\hline Agricultural exports do not granger cause agricultural GDP & 0.008 & 0.927 & No causality \\
\hline Agricultural GDP does not granger cause agricultural exports & 1.090 & 0.305 & \\
\hline
\end{tabular}

Note: The table presents the direction of causality of the variables.

\subsection{Decision Rule}

$\boldsymbol{H}_{\mathbf{0}}$ : There exists no causality between the variables (Uni-directional or Bi-directional).

$\boldsymbol{H}_{\mathbf{1}}$ : There exists causality between the variables (Uni-directional or Bi-directional).

The null hypothesis $\left(H_{0}\right)$ of no causality is accepted and by implication, the variables; Total exports, manufacturing GDP, agricultural GDP, manufacturing exports and agricultural exports are independent of one another. This direction of causality results for 1981 to 2013 does not provide pragmatic support for the export-led growth in the Nigerian economy. 
The ADF test results of the first sample period showed that the GDP growth was stationary at a level without trend, while exports/GDP ratio was stationary at the first differencing. Given the unit root properties, the results do not support the use of the Engle-Granger method of cointegration since the two variables tested for this period are not I(1). The VAR Granger causality test result of the first sample period, showed no causality existing between exports and the GDP growth from which it can be concluded that the huge earnings from exports have not made any significant contribution to the economic growth of Nigeria for this period data. The results for this period of data do not give evidence to support the export-led growth. The ADF test results of the other two sample periods showed that all the variables were stationary at a level without a trend. The results of the ADF test results for the other two sample periods also do not support the use of the Engle-Granger method of cointegration because they are not I(1) variables. Following the VAR results of 1970 to 2013, there was no evidence of a causal relationship existing between the GDP growth and the other variables: imports/GDP ratio, real interest rate and exports/GDP ratio.

The findings for this last period of data do not support export-led growth. These findings support Dawe (1996), cited in Dreger and Herzer (2011) who concluded that increased exports may lead to macroeconomic uncertainty, which, in turn, may be detrimental to economic planning and the efficiency of domestic investment. Nevertheless, the contrapositive view can also be found in the empirical literature. For example, Ekpo and Egwaikhide (1994), Fajana (1979) and Langley (1968) cited in Ojide and Ogbodo (2014) who found that exports have been contributing to Nigeria's growth, suggesting that, the export-led growth hypothesis holds.

\section{Conclusion and Recommendation}

\subsection{Conclusion}

Based on the empirical findings, it can be concluded from this study that exports do not influence and cannot sustain economic growth in the Nigerian economy and which does not provide evidence for the export-led growth in the Nigerian economy. The study recommends that the government attempt towards executing an economic policy that will strengthen economic growth such as import substitution strategy, to affect more on exports. This strategy will help to reduce the poverty level; as new industries will be created which will generate more employment opportunities. By giving enticement through granting training support to farmers which includes extension services and subsidisation of farm inputs such as fertilizer and high-quality seeds which will assist to improve the exports of the agricultural sector as well as the manufacturing sector.

\section{References}

Akihiro, K. (2011). Trade and economic growth: Is export-led growth passé? Economics Bulletin, 31(2), 16231630.

Alimi, S. R., \& Muse, B. O. (2012). Export-led growth or growth - driven exports? Evidence from Nigeria. British Journal of Economics, Management \& Trade, 3(2), 89-100. https://doi.org/10.9734/BJEMT/2013/2386

Budina, N., \& Pang, G. (2007). Nigeria’s Growth Record: Dutch Disease or Debt Overhang? World Bank Policy Research Working Paper 4256 (June 2007) 1-32.

Central Bank of Nigeria. (1993). Available at http://www.cenbank.org/MonetaryPolicy/policy.asp (Accessed: 13 September 2013).

Central Intelligence Agency. (2014). Nigeria. In The World Facebook. Available from Retrieved June 10th, 2015 from https://www.cia.gov/library/publications/the-world-factbook/geos/ni.html

Comparative advantage. Business Dictionary.com (no date). Retrieved August 30th, 2015 from http://www.businessdictionary.com/definition/comparative-advantage.html

Dreger, C., \& Herzer, D. (2011). A further examination of the export-led growth hypothesis, Discussion paper//European University Viadrina, Department of Business Administration and Economics, No. 305. ISSN 1860 0921. pp. 1-40.

Dritsakis, N. (2005). Exports and economic growth: an annual empirical investigation of EU, USA and Japan using causality tests, Department of Applied Informatics, University of Macedonia, Economics and Social Sciences. Cited in Achchuthan, S. Journal of Economics and Sustainable Development, 4(9), 148-150. ISSN 2222-1700 (paper) ISSN 222-2885 (Online).

Dumping. Business Dictionary.com (no date). Retrieved September 13th, 2015 from http://www.businessdictionary.com/definition/comparative-advantage.html

Ekpo \& Umoh. Retrieved September 13th, 2015 from http:/www.onlinenigeria.com/economics 
Herrerias, M. J., \& Vincente, O. (2010). Is the Export-Led Growth Hypothesis Enough to Account for China's Growth? China \& World Economy, 18(4), 34-51. https://doi.org/10.1111/j.1749-124X.2010.01203.x

Ibrahim, Ayodele A., Hakeem M. and Yinka, Adeniran A. (2014). Oil price shocks and Nigerian Economic growth. European Scientific Journal, 10(19). ISSN: 1857-7881.

James, S. H., \& Mark, W. W. (2012): Introduction to Econometrics. $3^{\text {rd }}$ eds. Pearson Education Limited. ISBN 9780-13-800900-7. pp 276-677.

Mahadevan, R. (2007). New Evidence on the Export-led Growth Nexus: A Case Study of Malaysia. The World Economy, 1069-1083. https://doi.org/10.1111/j.1467-9701.2007.01030.x

Makua, C. G. O., Kelechi, C. O., \& Joseph, O. C. (2014). Export-led Growth Hypothesis in Nigeria: Applications of ARDL Model and Co-integration Analysis. Global Journal of Emerging Market Economies, 6(1), 5-13. https://doi.org/10.1177/0974910113511190

Maximilian, B. (2011). How export-led growth can lead to take-off. Working Paper, 222, 1-17. ISSN 1860-5508.

Musley, D. (2004). Exports, Imports, and Economic Growth in South Asia: Evidence Using a Multivariate Timeseries Framework. The Pakistan Development Review, 43(2), 109-114. https://doi.org/10.30541/v43i2pp.105124

Okuneye, P. A., Fabusoro, E. K., Adebayo, \& Ayinde, I. A. (2004). The Nigerian agriculture and poverty incidence: The need for private sector empowerment. Paper prepared for presentation at the Farm Management Association of Nigeria Conference, Abuja, Nigeria Oct. 19-21, 54-65.

Okuntola, B. (2012). The Babangida Years and Private Sector Initiatives in the Restructuring of the Nigerian Economy, 1985-1993. African Nebula, 5, 32-41.

Olaniyi, E. (2013). Testing Finance-Led, Export-Led and Import-Led Growth Hypotheses on Four Sub-Saharan African Economies. MPRA Paper, No. 52460, 1-53. Retrieved from http://mpra.ub.uni-muenchen.de/52460/

Palley, T. I. (2000). Export-Led Growth: Evidence of Developing Country Crowding-Out. Published in Economic Integration, Regionalism, and Globalization, Arestis, Baddeley \& Mc Combie (eds.), Cheltenham: Edward Elgar, 2003. Pp. 1-28.

Tuck, T. C., \& Ravin, C. (2013). Export-Led Growth in Cambodia: An Empirical Study. Economics Bulletin, 33(1), $1-10$.

UK Essays. (November 2013). Import Substitution Policy versus Export-Led Growth Strategy Economics Essay. Retrieved August 30 $0^{\text {th }}, 2015$ from http://www.ukessays.com/essays/economics/import-substitution-policyversus-export-led-growth-strategy-economics-essay.php?cref $=1$

\section{Copyrights}

Copyright for this article is retained by the author(s), with first publication rights granted to the journal.

This is an open-access article distributed under the terms and conditions of the Creative Commons Attribution license (http://creativecommons.org/licenses/by/4.0/). 